
Digitized by the Internet Archive in 2012 with funding from

Agriculture and Agri-Food Canada - Agriculture et Agroalimentaire Canada 
DOMINION OF CANADA-DEPARTMENT OF AGRICULTURE SCIENCE SERVICE

\section{FIRE-BLIGHT OF APPLES AND PEARS}

Fire-blight is a bacterial disease of apple, pear, quince, hawthorn, mountain ash, and many other plants of the rose family. It is caused by Bacillus amylovorus (Burr.) Trev.

The bacteria attack and kill blossoms and twigs, causing what is known as "blossom blight" and "twig blight," respectively. When the infected twigs are numerous, the trees appear as if they had been scorched by fire, hence the name "fire-blight." The leaves of the affected twigs remain on the trees all summer and well on into the winter. The bacteria also cause dead areas, which are referred to as "cankers," on twigs, branches, and trunk.

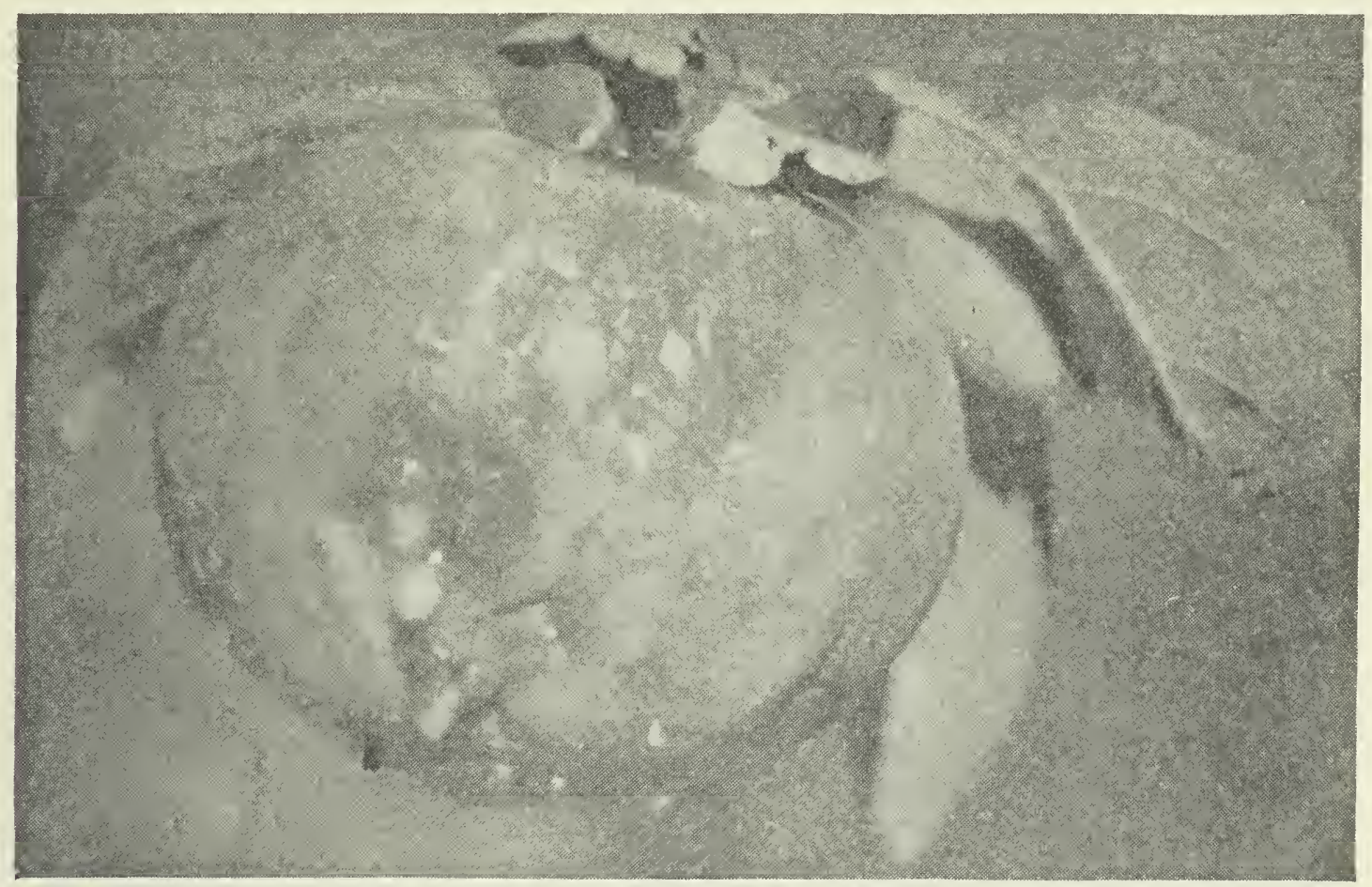

Diseased, green Alexander apple bearing numerous drops of ooze filled with the fire-blight bacteria.

The fire-blight bacteria overwinter in the living tissues at the margin of the cankers, which are referred to as "hold-over" cankers. In spring, ooze, containing myriads of fire-blight bacteria is exuded, from some of the holdover cankers. Rain washes off the ooze and spatters the bacteria about, resulting in new infections on twigs and blossoms near and below the cankers. Pollinating insects may at this time spread the disease from blossom to blossom, tree to tree, and orchard to orchard. As soon as new infections appear, drops of ooze may be found on the diseased leaf stalks, fruit stems, young fruits, and twigs. Again, rain washes off this ooze and splashes the bacteria on other twigs, causing more new infections.

The disease may progress down twigs into larger branches and trunk, where large cankers may result, sometimes girdling and killing them. Sprouts at the base of the trees, and water shoots on the trunk and large limbs, are very subject 98517 
to remove or scrape off the outer brown corky bark on and well beyond the cankers, and to treat these areas with the disinfectant recommended below. This disinfectant penetrates sufficiently to kill the bacteria, and yet does not kill the tree. The pruning of diseased branches and twigs, and the treating of cankers should be done thoroughly in order to eliminate all "hold-over" cankers. Experiments have shown that the bacteria can and frequently do overwinter in twigs $\frac{1}{4}$-inch or less in diameter. Therefore, even the smallest infected twigs, which are frequently at the top of the trees, and from which the bacteria may easily be scattered all over the tree, should all be removed. Care should be taken, in apple trees, to cut at least 6 inches below the diseased area, as the living bacteria extend beyond the visibly affected parts. In the case of highiy susceptible pear varieties, such as Clapp's Favourite and Flemish Beauty, one should cut from 1 to 2 feet below the visibly diseased part, as the blight progresses much more rapidly, and the bacteria extend much farther beyond the visibly diseased parts in these than in apple trees. If, after this careful dormant pruning, any fire-blight should appear in the spring, it should be cut off immediately and burned, preferably before rain, for the reasons explained above.

In pruning during the summer, the tools should be kept moistened with a disinfectant in order not to spread the blight, for it is impossible not to cut now and then through an infected area, contaminate the tools, and thus spread the disease, unless the tools are disinfected. Mercuric chloride (1-1,000) or formalin (1-300) may be used as disinfectants, but the following solution is specially recommended: 3 quarts of glycerine and 1 quart of water, mixed and heated to about $170^{\circ} \mathrm{F}$., in which are dissolved, in the order given, $\frac{1}{4} \mathrm{oz}$. cyanide of mercury and $\frac{1}{4} \mathrm{oz}$. bichloride of mercury. Glass containers must be used for this solution.

Caution.-As this is a deadly poison and glycerine has a sweetish taste, care must be taken to keep this solution out of reach of children and anmals. A smaller quantity of the disinfectant can be prepared, but this can best be done by a druggist. The average fruit grower will not use more than one or two pints per season. If the pruning is done during the fall or winter, when the trees are dormant, the tools need not be disinfected, as they will not then spread the disease.

Experiments in pruning out fire-blight in badly infected Fameuse trees, about 20 years old, were carried out in March, 1931. Careful cost data were kept. The rate of wages paid the workmen was 25 cents per hour. It cost an average of 56 cents per tree to prune out the fire-blight infections from these trees. From these figures, it is estimated that at the same rate of wage: the average cost of pruning out fire-blight in the largest and most seriously infected trees would not exceed $\$ 2$. In smaller trees, and in less severely infected ones, the cost would be proportionately less. The expenditure of from 50 cents to $\$ 2$ will frequently save a tree worth $\$ 100$ or more; in such a case this is surely a sound investment.

Each workman should be supplied with a ladder, a pruning saw, pruning shears and a pint jar of the perfect-seal type, with a stout wire hook on the handle with which to hang the jar on the ladder or on a limb within easy 


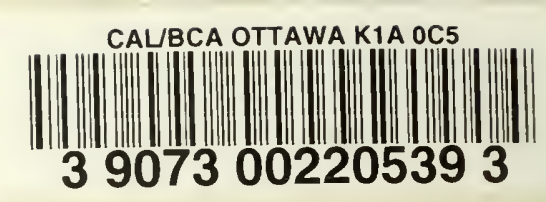

4

reach. The jar should contain about two inches of the disinfectant, a stainless steel paring knife and a one-inch paint brush. The knife is used to cut or scrape off the outer brown corky bark on and around the cankers, and the paint brush to paint over these scarified areas and to disinfect the pruning saw. The pruning shears should be kept moistened with the disinfectant by frequently dipping them into the jar.

The bacteria overwinter more frequently on trees of highly susceptible varieties than on the trees of the more resistant varieties. Crabapples and some varieties of apples, such as Alexander, Winter Arabka, Tetofski, and many others, have little commercial value to-day, and yet are most susceptible to fire-blight, and a source of infection to the other trees in the orchard. These varieties should be cut down in order to protect the better varieties. Many mountain ash trees and hawthorn shrubs, whether planted for ornamental purposes or growing wild, and many wild apple trees, are very susceptible to and frequently infected with fire-blight. They should also be cut down, in order to protect commercial orchards.

H. N. RACICOT,

Associate Plant Pathologist, Division of Botany and Plant Pathology, Ottawa, Ontario. 